\title{
CHINCHILLIDAE AND DOLICHOTINAE RODENTS (RODENTIA: HYSTRICOGNATHI: CAVIOMORPHA) FROM THE LATE PLEISTOCENE OF SOUTHERN BRAZIL
}

\author{
LEONARDO KERBER \\ Seção de Paleontologia, Museu de Ciências Naturais, Fundação Zoobotânica do Rio Grande do Sul, Av. Salvador França, \\ 1427, 90690-000, Porto Alegre, RS, Brasil.leonardokerber@gmail.com \\ RENATO PEREIRALOPES \\ Setor de Paleontologia, Instituto de Oceanografia, Universidade Federal do Rio Grande, Av. Itália, km 08, 96201-900, Rio \\ Grande, RS, Brasil.paleonto_furg@yahoo.com.br \\ MARIA GUIOMAR VUCETICH \\ División Paleontología Vertebrados, Museo de La Plata, Paseo del Bosque s/n, B1900FWA, La Plata, \\ Argentina.vucetich@fcnym.unlp.edu.ar
}

ANA MARIA RIBEIRO

Seção de Paleontologia, Museu de Ciências Naturais, Fundação Zoobotânica do Rio Grande do Sul, Av. Salvador França, 1427, 90690-000, Porto Alegre, RS, Brasil.ana.ribeiro@fzb.rs.gov.br

\begin{abstract}
JAMIL PEREIRA
Museu Coronel Tancredo Fernandes de Mello, Rua Barão do Rio Branco, 467, Santa Vitória do Palmar, RS, Brasil. jamil_pereira@terra.com.br
\end{abstract}

\begin{abstract}
New records of rodents from the late Pleistocene Chuí Creek, Rio Grande do Sul State, southern Brazil, are here described. A partial dentary with fragmented cheek teeth is identified as Chinchillidae, Lagostomus Brookes cf. L. maximus (Desmarest). Other two specimens are identified as cheek teeth of Dolichotinae indet. (Caviidae). Pleistocene fossils of Lagostomus were previously reported for Argentina and Uruguay. The material of Lagostomus from Chuí Creek represents the first confidently record of this taxon Brazil. Pleistocene fossil remains of Dolichotinae have been found in Argentina, Uruguay and other areas of southern Brazil, though the Brazilian find lack precise stratigraphic information. These new records widen the paleobiogeographic distribution of Lagostomus and confirm the presence of Dolichotinae during the late Pleistocene of southern Brazil.
\end{abstract}

Key words: Lagostomus, Lagostominae, Dolichotinae, Chuí Creek, Rio Grande do Sul, Quaternary.

RESUMO - Este trabalho reporta novos materiais de roedores provenientes dos depósitos fossilíferos do arroio Chuí (Rio Grande do Sul, sul do Brasil). O material de Chinchillidae é identificado como Lagostomus Brookes cf. L. maximus (Desmarest) e é representado por um dentário esquerdo faltando sua região posterior, com o incisivo preservado e a série p4-m3 fragmentada. Os outros dois espécimes são identificados como molariformes de Dolichotinae indet. (Caviidae). Os fósseis de Lagostomus durante o Pleistoceno estavam restritos a Argentina e Uruguai. O material aqui reportado caracteriza o primeiro registro seguro deste táxon no Brasil. Fósseis de Dolichotinae têm sido encontrados em depósitos pleistocênicos da Argentina, Uruguai e sul do Brasil, porém este último provém de uma localidade sem contexto estratigráfico preciso. Desta forma, estes novos registros ampliam a distribuição paleobiogeográfica de Lagostomus e confirmam a presença de Dolichotinae durante o Pleistoceno final do sul do Brasil.

Palavras-chave: Lagostomus, Lagostominae, Dolichotinae, arroio Chuí, Rio Grande do Sul, Quaternário.

\section{INTRODUCTION}

Chinchillidae are South American hystricognath rodents that include the extant chinchillas (Chinchilla Bennett, 1829), mountain vizcachas (Lagidium Meyen, 1833) and pampas vizcachas (Lagostomus Brookes, 1828). The stratigraphic distribution of Chinchillidae extends from Eocene/early Oligocene to Recent (Vucetich et al., 1999, 2010; Flynn et al., 
2003). Molecular studies confirmed that the extant Chinchillidae are a monophyletic group (Spotorno et al., 2004) and suggest a close relationship with Dinomyidae (Huchon \& Douzery, 2001). Extant chinchillids have euhypsodont cheek teeth, composed of laminar and oblique prisms, labially (upper teeth) or lingually (lower teeth) united, with a very thin interlaminar cement layer, bullae well developed and locomotion partially saltatory (Wood, 1955; Bondesio et al., 1975). According to Pocock (1922), Chinchillidae includes two subfamilies, Chinchillinae and Lagostominae. Chinchillines have cheek teeth with two flexi/flexids and three lophs/ids, and the lagostomines have two lophs/ids, separated by only one flexus/flexid. Lagostomines are represented in the fossil record since the Oligocene (Vucetich et al., 1999, 2010). For the Pliocene and Pleistocene, two genera have been described: Lagostomopsis Kraglievich, 1926 from Montehermosan and Chapadmalalan ages, and Lagostomus from Barrancalobian to Recent (Vucetich \& Verzi, 1995). However, according to Vucetich \& Verzi (1995) the differences between these taxa are mainly of size. In the absence of more diagnostic characters, Vucetich \& Verzi (1995) suggested that the only valid genus in the Pliocene/ Pleistocene is Lagostomus. The same problem is present in the extinct species of Lagostomus because their diagnoses are also based on size (see Gervais \& Ameghino, 1880), which is quite variable in the living Lagostomus (Llanos \& Crespo, 1952). The current taxonomy of the family and extinct species of Lagostomus needs review (Vucetich \& Verzi, 1995; Candela, 2005), as well as cladistic analyses, including fossil and extant taxa.

Caviidae are taxonomically diverse caviomorphs, often small and cursorial, with euhypsodont cheek teeth (Wood, 1955). The group originated in the middle/late Miocene (Vucetich et al., 1999) and achieved its greatest diversity during the late Pliocene (Quintana, 1997). According to Paula Couto (1979), the family includes an extinct subfamily, the Cardiomyinae (but see Pérez, 2010), and two extant subfamilies, the Caviinae and the Dolichotinae. Dolichotines share the following characters: the skull with the foramen magnum displaced ventrally, diastema longer than P4-M3 series, absent nasolacrimal foramen on the maxilla, and mesopterygoid fossa reaching the M2 (Paula Couto, 1979; Quintana, 1998; Ubilla \& Rinderknecht, 2003). The Quaternary dolichotines are represented by a single genus, Dolichotis Desmarest, 1820 (including Pediolagus), with two species, D. patagonum Zimmermann, 1780 and D. salinicola (Burmeister, 1876).

Until now, the Pleistocene fossil record of caviomorph rodents in southern Brazil only included Caviidae, Hydrochoeridae and Echimyidae. For the continental shelf of Rio Grande do Sul State (RS), Rodrigues \& Ferigolo (2004) described several teeth and a fragment of a dentary of Myocastor coypus (Molina, 1782), a P4 of Dolichotinae indet., and a dentary of Eumysopinae indet. For Chuí Creek, southernmost of RS, Ubilla et al. (2008) reported cranial fragments and postcranial elements of Microcavia Gervais \& Ameghino, 1880. From Touro Passo Formation, remains of H. hydrochaeris (Linnaeus, 1766), Caviidae indet., and Galea Meyen, 1832 have been recognized (Kerber \& Oliveira, 2008; Kerber \& Ribeiro, 2011; Kerber et al., 2011) and for Quaraí River, Oliveira (1992) referred H. hydrochaeris.

This paper reports new remains assigned to a Chinchillidae and a Dolichotinae from Chuí Creek (upper Pleistocene), southern Brazil and discusses the late Pleistocene fossil record of both taxa as well as the paleobiogeographic implications of these findings.

\section{MATERIAL AND METHODS}

The specimens studied herein are stored in the paleovertebrate collection of Museu Coronel Tancredo Fernandes de Melo (MCTFM in Santa Vitória do Palmar, RS) and Laboratório de Geologia e Paleontologia da Universidade Federal do Rio Grande (LGP-V in Rio Grande, RS).

The material of Chinchillidae was compared to the extant chinchillids Lagostomus maximus (Desmarest, 1817), Chinchilla and Lagidium (from Argentina); and the Dolichotinae were compared with the caviids Dolichotis patagonum, D. salinicola, Microcavia, Galea (from Argentina) and Kerodon F. Cuvier, 1825 (from northeast Brazil) (Appendix 1). Traditionally, Kerodon was considered a Caviinae. However, in recent papers, using molecular and paleontological evidence, it has been considered more closely related to Hydrochoeridae (Rowe \& Honeycutt, 2002; Pérez, 2010). It was included in this comparison because it shares several dental features with Caviidae.

The mandibular nomenclature follows Woods \& Howland (1979) and Pérez (2010), and the dental nomenclature of Caviidae follows Quintana (1996). The measurements were taken with a digital caliper accurate to $0.01 \mathrm{~mm}$ and stereomicroscope, and are expressed in millimeters.

Institutional abbreviations. LGP-V, Laboratório de Geologia e Paleontologia, Universidade Federal do Rio Grande (FURG), Rio Grande, RS, Brazil; MCN-M, Coleção de Mamíferos do Museu de Ciências Naturais da Fundação Zoobotânica do Rio Grande do Sul, Porto Alegre, RS, Brazil; MCPU-M, Coleção de Mastozoologia do Museu de Ciências da Pontifícia Universidade Católica do Rio Grande do Sul, Porto Alegre, RS, Brazil; MCTFM, Museu Coronel Tancredo Fernandes de Melo, Santa Vitória do Palmar, RS, Brazil; MDJ-Mr, Coleção de Mamíferos recentes do Laboratório de Paleontologia do Museu Dom José, Sobral, Ceará State, Brazil; MLP, Colección de Mastozoología, Museo de La Plata, La Plata, Buenos Aires Province, Argentina.

\section{LOCATION AND GEOLOGICAL SETTING}

Chuí Creek $\left(53^{\circ} 23 \mathrm{~S}, 33^{\circ} 22 \mathrm{~W}\right)$ is located in southernmost Brazil, and is part of the Coastal Plain of Rio Grande do Sul State (PCRS) (Figure 1). Late Pleistocene mammal remains of 
Lujanian age [Equus (A.) neogaeus Biozone, sensu Cione \& Tonni, 1999] are found in Chuí Creek (Oliveira et al., 2005), collected from a $\sim 1.5$ meter-thick muddy sandstone bed (Lopes et al., 2001, 2005). The fossils are found articulated or isolated, mostly fragmented, but sometimes complete and well-preserved specimens, probably deposited and reworked in a meandering fluvial system. According to Buchmann et al. (2009) the presence of a fossiliferous bed, lenses of organic matter-rich sediments interpreted as abandoned meanders (oxbow lakes), a high proportion of fossils broken after burial, and occurrence of fossils at a considerable distance from the present course of the creek, suggest that the fossils were accumulated and reworked in a wide flood plain. Lopes et al. (2010) dated teeth of megamammals from the fossiliferous level using Electron Spin Resonance, showing ages between 42 and $33 \mathrm{Ka} \mathrm{BP}$. The fossiliferous bed contains fossils of large-bodied mammals, mostly herbivores, including xenarthrans and ungulates, while carnivores are very scarce in comparison (Oliveira, 1992; Oliveira et al., 2005; Marcon, 2008; Oliveira \& Pereira, 2009; Scherer et al., 2009; Lopes \& Pereira, 2010). Remains of medium- and small-sized mammals are scarcely represented.
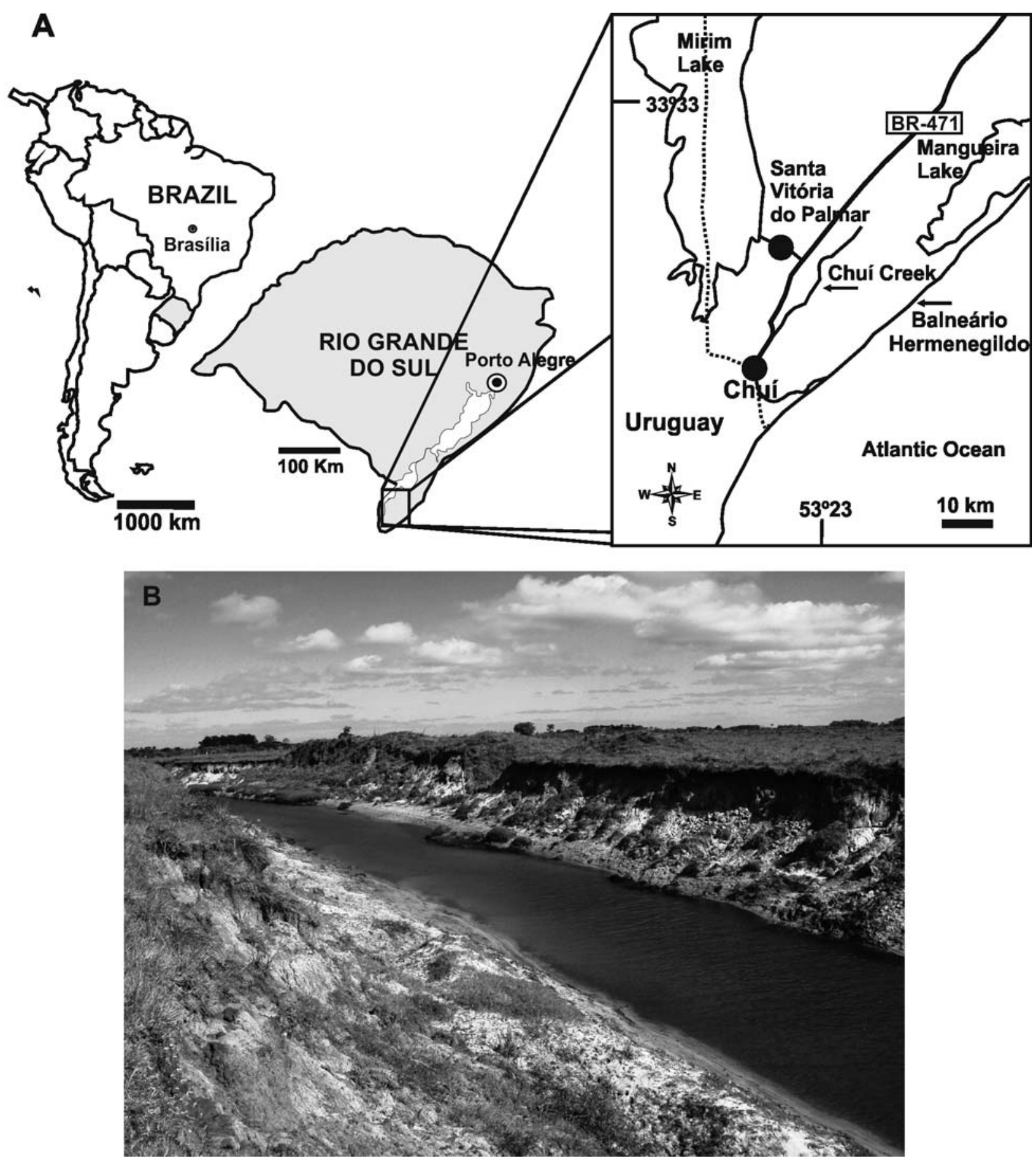

Figure 1. A, Geographical location of Chuí Creek; B, Panoramic view of Chuí Creek. 


\section{SYSTEMATIC PALEONTOLOGY}

RODENTIA Bowdich, 1821

HYSTRICOGNATHI Tullberg, 1899

CAVIOMORPHA Wood \& Patterson (in Wood, 1955)

CHINCHILLOIDEA Kraglievich, 1940

CHINCHILLIDAE Bennett, 1833

LAGOSTOMINAE Wiegman, 1832

Lagostomus Brookes, 1828

Lagostomus cf. L. maximus (Desmarest, 1817) (Figure 2)

Material. MCTFM-PV 0769, left dentary lacking the posterior portion, with very fragmented cheek teeth.

Geographical and stratigraphic provenance. Chuí Creek, in the upper portion of the muddy sandstone bed. Santa Vitória do Palmar, Rio Grande do Sul State, Brazil.

Description and comparison. The dorsal area of the diastema is thin and forms a tenuous crest that extends from the mesial face of $\mathrm{p} 4$ alveolus up to the symphysis. The alveolus of the incisor forms a well-developed prominence on the medial surface of the dentary, which extends up to the level of $\mathrm{m} 3$, as in Lagostomus maximus and different from Chinchilla and Lagidium, in which it extends up to the $\mathrm{m} 1 / \mathrm{m} 2$ level. The coronoid process is located at the level of the distal area of the $\mathrm{m} 3$ alveolus, being posteriorly oriented. This process is thin and is different from Chinchilla and Lagidium, in which it is located posteriorly to the $\mathrm{m} 3$ and more vertical. The lunar notch is deeper than in Chinchilla and Lagidium. The mandibular foramen is located on the dorsal surface of the dentary, posteromedially to the $\mathrm{m} 3$ alveolus. The notch for the insertion of the tendon of the masseter medialis pars infraorbitalis muscle is located below $\mathrm{m} 1$ and $\mathrm{m} 2$, as in $L$. maximus and Lagidium, while in Chinchilla the notch is below $\mathrm{m} 1$. The incisor is slightly longitudinally striated on the labial face. The cheek teeth are very fragmented, but it can be seen that they are bilophodont and obliquely oriented, features that characterize Lagostominae. In size, MCTFMPV 0769 is smaller than the adult males of L. maximus, but more similar to the young males and adult females analyzed (Table 1).

$$
\begin{gathered}
\text { CAVIOIDEA Fischer de Waldheim, } 1817 \\
\text { CAVIIDAE Fischer de Waldheim, } 1817 \\
\text { DOLICHOTINAE Pocock, } 1922 \\
\text { Dolichotinae indet. } \\
\text { (Figure 3) }
\end{gathered}
$$

Material. Isolated left $\mathrm{m} 1$ or $\mathrm{m} 2$, lacking the lingual end of Pr. II (MCTFM-PV 0736) plus another poorly preserved tooth (LGP-V 0001).

Geographic and stratigraphic provenance. Chuí Creek, MCTFM-PV 0736 was recovered from sediments dredged from the bottom of the creek, while LGP-V 0001 was found in the muddy sandstone bed. Santa Vitória do Palmar, Rio Grande do Sul State, Brazil.

Description and comparison. The description is based on MCTFM-PV 0736, which is the best preserved, but the same characters are also observed in LGP-V 0001. MCTFMPV 0736 is euhypsodont and biprismatic (Figure 3A). It has a linguolabial curvature (Figure $3 \mathrm{~B}$ ) and is slightly mesiodistally curved, with the apex more distal than the occlusal surface (Figures 3C-D), characterizing a lower tooth.

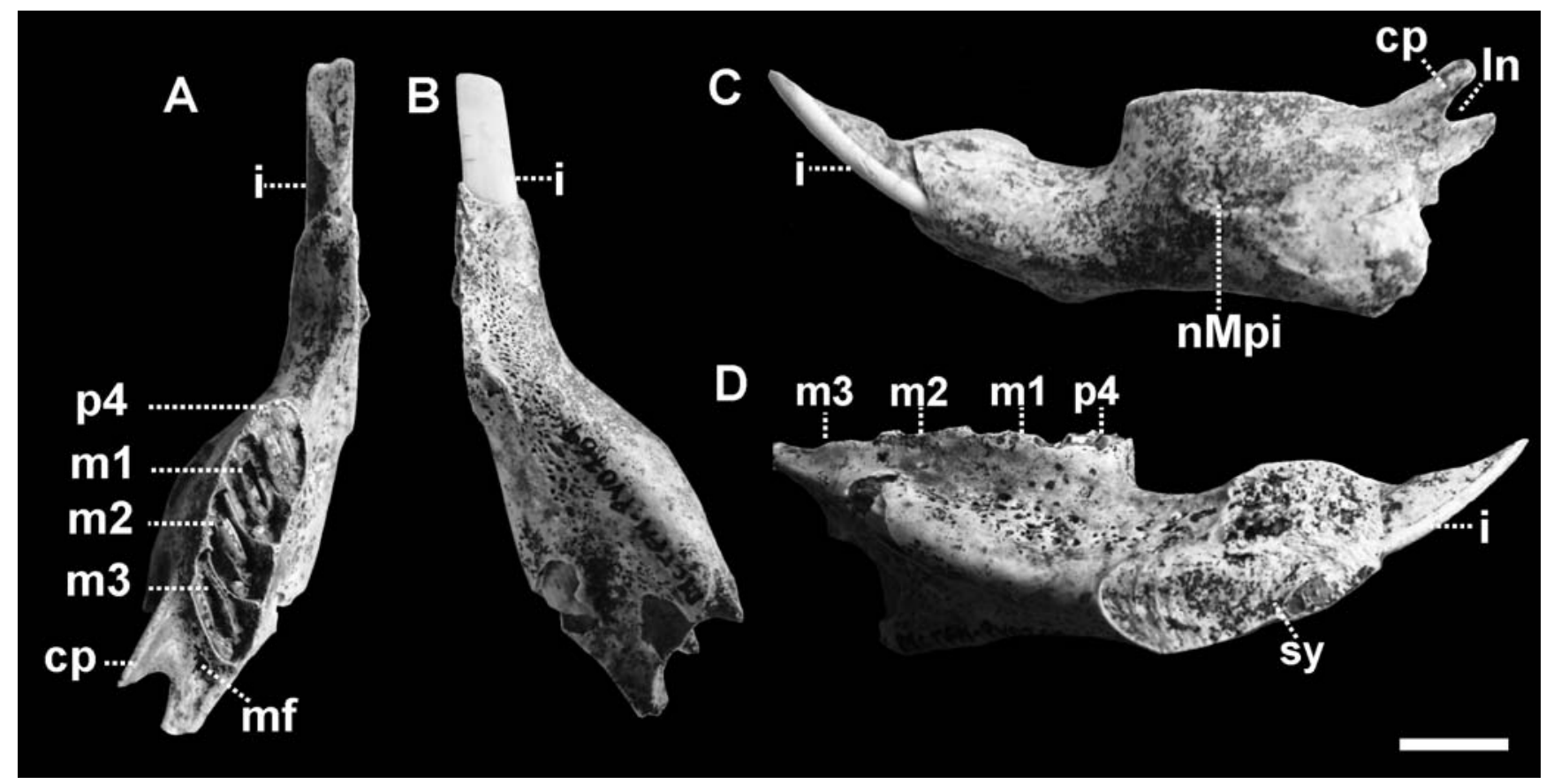

Figure 2. Lagostomus cf. L. maximus (MCTFM-PV 0769) from Chuí Creek, in occlusal (A), ventral (B), lateral (C) and medial (D) views. Abbreviations: $\mathbf{c p}$, coronoid process; In, lunar notch; $\mathbf{m f}$, mandibular foramen; nMpi, notch for insertion of the tendon of the masseter medialis pars infraorbitalis muscle; $\mathbf{i}$, incisor; p4, fourth premolar; $\mathbf{m 1}$, first molar; $\mathbf{m} 2$, second molar; m3, third molar; sy, symphysis. Scale bar $=10 \mathrm{~mm}$. 

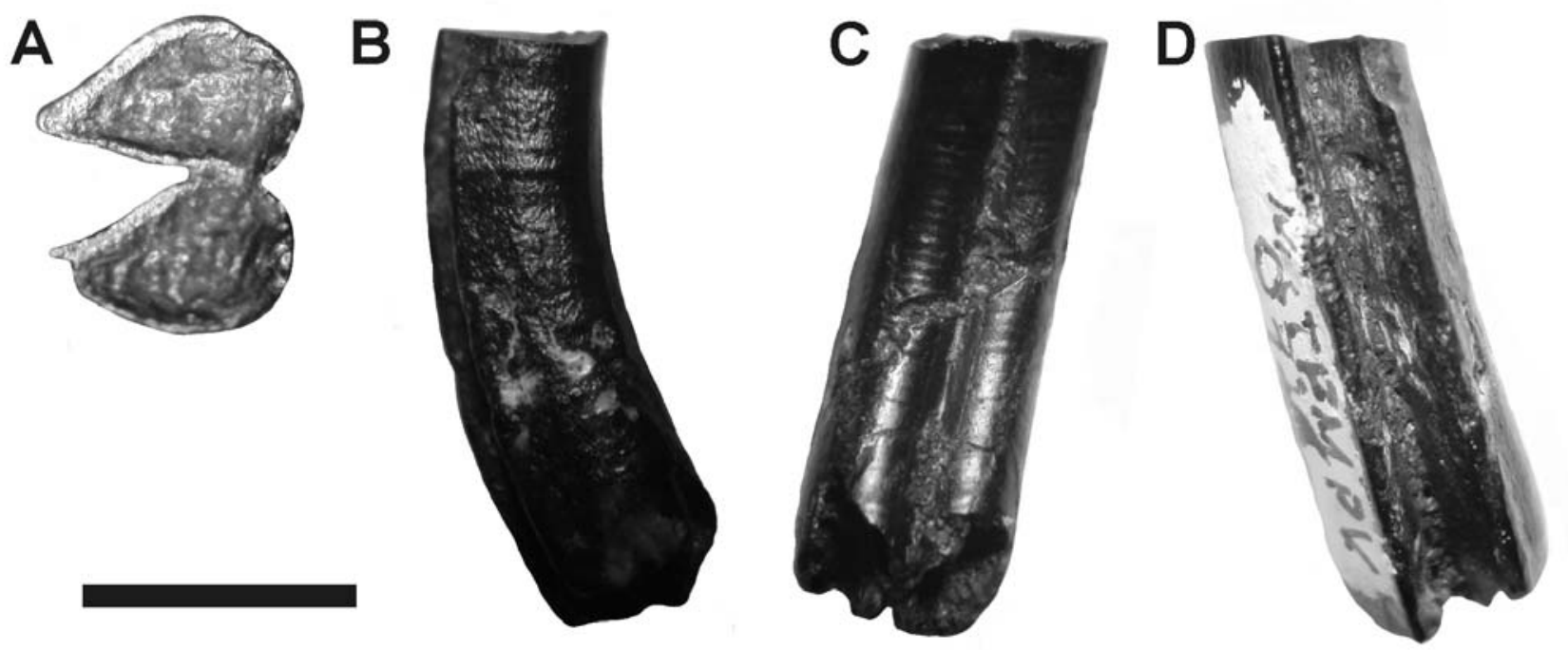

Figure 3. Left $m 1$ or $m 2$ of Dolichotinae (MCTFM-PV 0736) from Chuí Creek, in occlusal (A), distal (B), lingual (C) and labial (D) views. Scale bar: $A=4 \mathrm{~mm} ; \mathrm{B}, \mathrm{C}, \mathrm{D}=6 \mathrm{~mm}$.

Table 1. Measurements $(\mathrm{mm})$ of the specimen MCTFM-PV 0769 and comparative specimens (young and adults) of Lagostomus maximus. Since there is sexual dimorphism in L. maximus (Llanos \& Crespo, 1952), we separated the males $(n=7)$ from females $(n=10)$, and performed a statistic analysis with males, females and the specimens without determined sex $(n=22)$ to estimate variation within the species. Measurements: 1 , diastema length; 2 , height of the dentary body at the level of $p 4 ; 3$, length of $p 4-m 3$ alveolar series; 4 , mesiodistal length (MDL) of $p 4$ alveolus; 5, linguolabial width (LLW) of p4 alveolus; $6, \mathrm{MDL}$ of $\mathrm{m} 1$ alveolus; 7, LLW of $\mathrm{m} 1$ alveolus; 8, MDL of m2 alveolus; 9 , LLW of m2 alveolus; 10, MDL of $\mathrm{m} 3$ alveolus; 11 , LLW of $\mathrm{m} 3$ alveolus; 12 , width of the incisor. Abbreviations: M, measurements; $\mathbf{n}$, specimens; SD, standard deviation; (m) males; (f) females; * males, females plus the specimens without sex determined.

\begin{tabular}{|c|c|c|c|c|c|c|c|c|c|c|c|c|c|}
\hline & MCTFM-PV 0769 & \multicolumn{4}{|c|}{ L. maximus $(\mathrm{m})$} & \multicolumn{4}{|c|}{ L. maximus (f) } & \multicolumn{4}{|c|}{ L. maximus* } \\
\hline $\mathrm{M}$ & & $\mathrm{n}$ & Mean & $\operatorname{Min} / \operatorname{Max}$ & $\mathrm{SD}$ & $\mathrm{n}$ & Me an & Min/Max & $\mathrm{SD}$ & $\mathrm{n}$ & Mean & $\operatorname{Min} / \operatorname{Max}$ & $\mathrm{SD}$ \\
\hline 1 & 19.97 & 7 & 24.22 & $18.96 / 29.84$ & 4.14 & 9 & 20.15 & $17.87 / 23.15$ & 1.80 & 35 & 22.61 & $17.65 / 29.84$ & 3.90 \\
\hline 2 & 16.16 & 7 & 19.93 & $16.17 / 23.38$ & 2.88 & 9 & 16.46 & $14.22 / 18.81$ & 1.51 & 37 & 18.41 & $13.67 / 25.05$ & 3.23 \\
\hline 3 & 23.82 & 7 & 25.65 & $20.7 / 30.33$ & 3.57 & 9 & 23.49 & $19.84 / 25.82$ & 2.0 & 37 & 24.62 & $19.34 / 30.45$ & 3.23 \\
\hline 4 & 4.36 & 7 & 4.46 & $3.4 / 6.0$ & 0.93 & 9 & 4.29 & $3.33 / 5.16$ & 0.61 & 36 & 4.49 & $3.33 / 6.01$ & 0.70 \\
\hline 5 & 8.11 & 7 & 7.87 & $6.56 / 9.74$ & 1.03 & 9 & 6.98 & $5.6 / 8.39$ & 0.94 & 36 & 7.50 & $5.33 / 11.11$ & 1.28 \\
\hline 6 & 4.51 & 7 & 4.92 & $3.92 / 5.67$ & 0.70 & 9 & 4.64 & $3.98 / 5.73$ & 0.53 & 36 & 4.83 & $3.17 / 6.1$ & 4.83 \\
\hline 7 & 8.23 & 7 & 8.12 & $4.36 / 10.08$ & 1.90 & 9 & 7.58 & $5.78 / 9.01$ & 0.94 & 36 & 8.08 & $4.36 / 10.88$ & 1.42 \\
\hline 8 & 4.78 & 7 & 4.88 & $3.83 / 5.96$ & 0.72 & 9 & 4.93 & $4.16 / 7.68$ & 1.09 & 36 & 4.94 & $3.72 / 7.68$ & 0.84 \\
\hline 9 & 7.47 & 7 & 8.62 & $6.32 / 9.96$ & 1.29 & 9 & 7.59 & $6.74 / 8.35$ & 0.59 & 36 & 8.23 & $5.91 / 10.85$ & 1.34 \\
\hline 10 & 4.31 & 7 & 5.31 & $4.04 / 9.8$ & 2.02 & 9 & 4.64 & $4.0 / 5.37$ & 0.44 & 36 & 4.99 & $3.78 / 9.8$ & 1.11 \\
\hline 11 & 8.01 & 7 & 8.64 & $6.44 / 10.29$ & 1.42 & 9 & 7.62 & $5.54 / 8.49$ & 1.16 & 36 & 8.29 & $5.54 / 13.5$ & 1.65 \\
\hline 12 & 4.61 & 6 & 5.03 & $3.59 / 6.33$ & 1.08 & 9 & 4.27 & $3.31 / 4.79$ & 0.53 & 32 & 4.57 & $3.23 / 6.33$ & 0.93 \\
\hline
\end{tabular}

The hypoflexid is well developed, transversally oriented, and its lingual end largely surpasses the middle of the tooth. Opposite to the hypoflexid, there is a shallow furrow located between both prisms (Figure 3A). The prisms are transversally oriented, with similar size and shape, and are united by a thinner and shorter isthmus (Figure 3A) than those of the Galea, Microcavia and Kerodon (Figures 4A-C). The lingual area of the prisms is more convex than in Galea, Microcavia and Kerodon. The material is morphologically very similar to $D$. salinicola and $D$. patagonum (Figures $4 \mathrm{D}-\mathrm{E}$ ), but smaller than the adult specimens of D. patagonum (Table 2).

Dimensions (mm). Mesiodistal length, 4.28; linguolabial width, 3.5; height, 14.4.
Table 2. Measurements $(\mathrm{mm})$ of Dolichotis salinicola and $D$. patagonum. Abbreviations: MDL, mesiodistal length; LLW, linguolabial width.

\begin{tabular}{lcccc}
\hline \multicolumn{2}{c}{$\mathrm{m1}$} & \multicolumn{2}{c}{$\mathrm{m} 2$} \\
\hline & MDL & LLW & MDL & LLW \\
MLPalinicola & & & & \\
MLP 673 & 4.10 & 3.61 & 4.41 & 3.60 \\
D. patagonum & 4.76 & 3.99 & 4.56 & 3.57 \\
MLP 371 & & & & \\
MLP 8-XI-95-5 & ----- & ---- & ---- & ---- \\
MLP 488 & 5.19 & 4.60 & 5.49 & 4.64 \\
MLP 247 & 6.25 & 5.56 & 6.50 & 5.50 \\
MLP 371 & ----- & ----- & ---- & ---- \\
MLP 5-II-49-2 & 4.29 & 3.26 & 3.95 & 3.27 \\
MLP 1418 & 3.50 & 2.84 & 3.69 & 2.69 \\
& 5.63 & 5.97 & 5.54 & 4.84 \\
\hline
\end{tabular}




\section{DISCUSSION AND CONCLUSIONS}

The specimen MCTFM-PV 0769 is assigned to the genus Lagostomus based on the tooth structure with two oblique laminae, coronoid process located at the level of the distal area of the $\mathrm{m} 3$ alveolus and posteriorly oriented and striated incisor extending up to the $\mathrm{m} 3$ level. The material does not differ from L. maximus, but given its fragmentary status, it is assigned to Lagostomus cf. L. maximus.

The specimens MCTFM-PV 0736 and LGP-V 0001 are assigned to Dolichotinae based on the characteristic tooth structure of two chordiform lobes with only one poorlydeveloped external furrow opposite to the hypoflexid (Kraglievich, 1930). These characteristics are similar to Dolichotis (Figures 4D-E); however the material is scarce and there are no characters that allow it to be confidently assigned to a genus or species.

Today, Lagostomus maximus inhabits plains of southern Bolivia, western Paraguay and central Argentina (Figure 5A) (Llanos \& Crespo, 1952; Jackson et al., 1996 and references therein). Extant Dolichotinae are also represented in these regions, but reaching higher latitudes than Lagostomus (Cabrera, 1961; Eisenberg \& Redford, 1989; Campos et al., 2001 and references therein) (Figure 5B).

Previous confirmed Pleistocene records of Lagostomus were from Argentina and Uruguay (Figure 5A). The Danish naturalist Peter W. Lund (1841) mentioned a Lagostominae (Lagostomus brasiliensis) from the karst of Lagoa Santa (Minas Gerais State, Brazil), based on a fragmented dentary and one euhypsodont and bilaminar tooth (Lund, 1841:pl.
XXV, figs. 1-3; pl. XXVI, figs 1-4). However, in the review of Lagoa Santa rodents, Winge (1888) did not recognize this taxon (Paula Couto, 1950: footnotes 36 and 318). In fact, the drawings by Lund (1841) are not clear enough to identify this material. For example, the tooth is about 50\% narrower than in Lagostomus maximus. In addition, the occlusal design shows completely independent laminae separated by a thick layer of cement (Lund, 1841:pl. XXV, fig. 2a), even thicker than in Miocene lagostomines.

The confirmation of the presence of Lagostomus in the Quaternary from the Intertropical region of Brazil (sensu Cartelle, 1999) depends on the discovery of new remains. According to Cione et al. (1999), during the Quaternary of Argentina, Lagostomus first occurs in the Ensenadan. In Argentina, Lagostomus sp. is recorded for late Pleistocene in Buenos Aires Province at Punta Hermengo (Tonni \& Fidalgo, 1982) and Dolores locality (Chimento, 2007), and also in Córdoba Province (Cruz et al., 2009). L. maximus is a guide fossil for the Platan age (Holocene) (Cione \& Tonni, 1999), though the species also occurs in the late Pleistocene at Paso Otero (Prado et al., 1987) and Punta Hermengo, both in Buenos Aires Province (Tonni \& Fidalgo, 1982), and at Córdoba Province (Sarrat, 2009); and late Pleistocene/Holocene at Arroyo Seco 2 (Gómez et al., 1999) and Cueva Tixi, both in Buenos Aires Province (Tonni et al., 1988). In Uruguay, Lagostomus sp. was reported for the late Pleistocene at El Caño locality, and Libertad and Dolores formations (Ubilla \& Perea, 1999; Ubilla et al., 2009).

The Quaternary fossil record of Dolichotinae is very scarce. The only genus recognized is Dolichotis (Figure 5B),
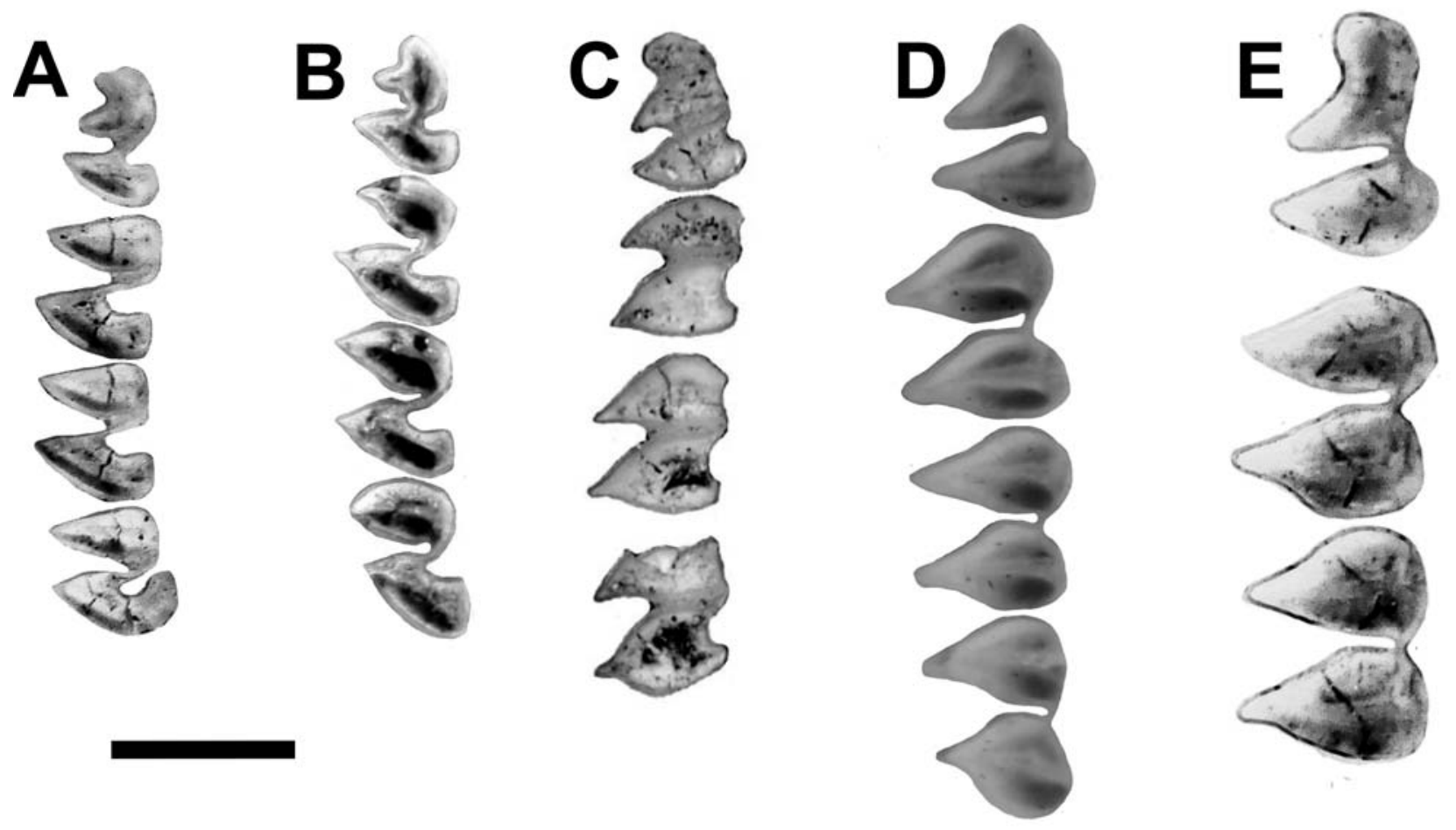

Figure 4. Lower left cheek teeth of Caviidae used for comparison with MCTFM-PV 0736 and LGP-V 0001. A, Galea musteloides, MLP 738 (4); B, Microcavia australis, MLP 683 (2); C, Kerodon rupestris, MDJ/Mr 002; D, Dolichotis salinicola, MLP 673; E, Dolichotis patagonum, MLP 8-XI-95.5 (p4-m2 series). Scale bar $=5 \mathrm{~mm}$. 


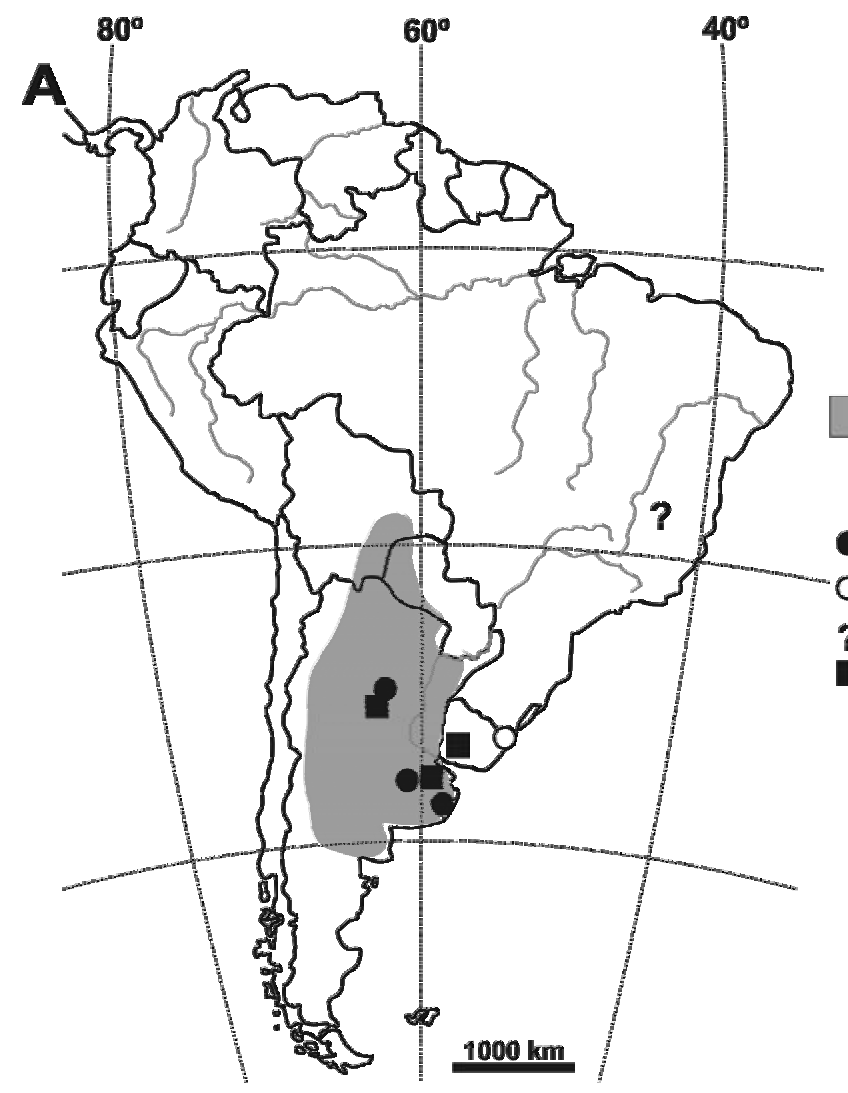

\section{Current distribution}

Lagostomus maximus

Late Pleistocene fossil record

- Lagostomus maximus

- Lagostomus cf. L. maximus

? "Lagostomus brasiliensis"

Lagostomus sp.

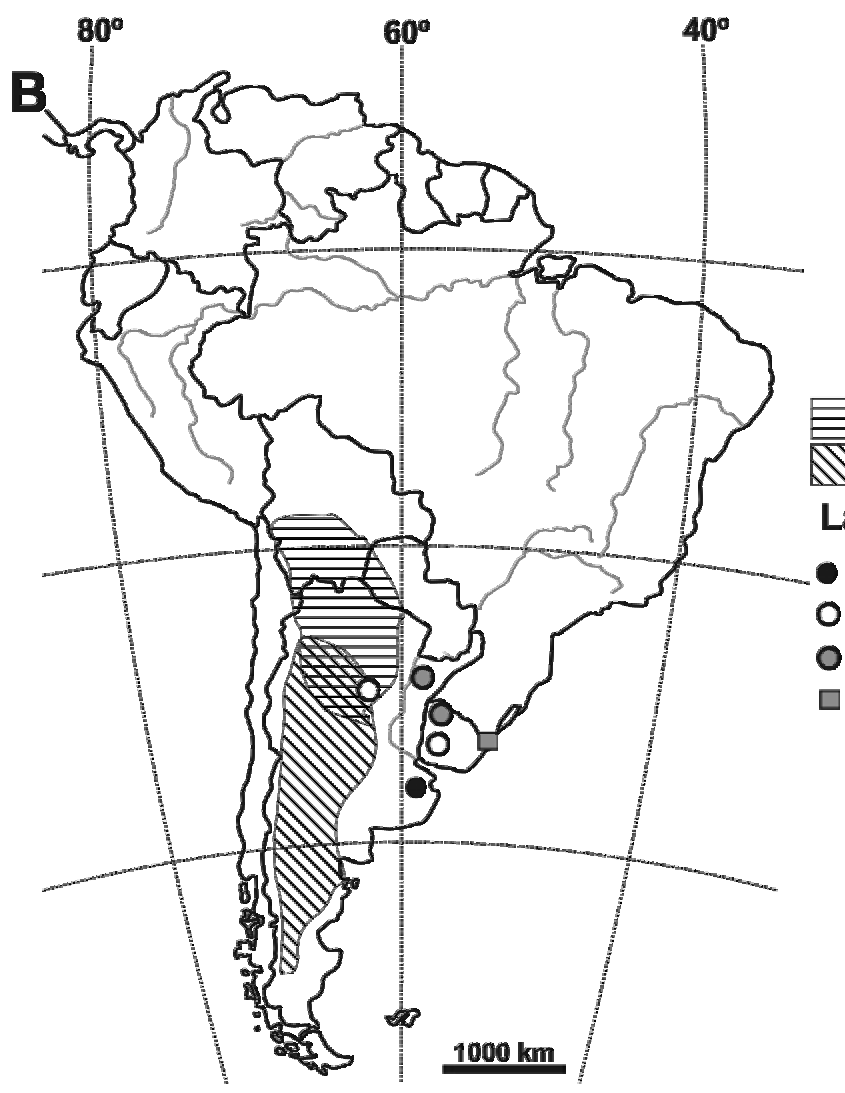

\section{Current distribution}

D. salinicola

D. patagonum

Late Pleistocene fossil record

Dolichotis salinicola

O Dolichotis cf. D. patagonum

- Dolichotis sp.

Dolichotinae indet.

Figure 5. A, Current distribution of Lagostomus (Llanos \& Crespo, 1952; Eisenberg \& Redford, 1989; Jackson et al., 1996) and its late Pleistocene fossil record. Fossil record based on: Tonni \& Fidalgo (1982), Prado et al. (1987), Tonni et al. (1988), Gómez et al. (1999), Ubilla \& Perea (1999), Sarrat (2009) and Ubilla et al. (2009). B, Distribution of extant Dolichotinae (Cabrera, 1961; Eisenberg \& Redford, 1989; Campos et al., 2001) and their late Pleistocene fossil record. Fossil record based on: Tonni (1981), Scillato-Yané et al. (1998), Ubilla et al. (2004), Sarrat (2009) and Ubilla et al. (2009). 
which is known from the late Pliocene at least (Vucetich \& Verzi, 1995; Verzi \& Quintana, 2005). In the late Pleistocene, Dolichotis sp. was reported for Arroyo Toropí, Corrientes Province, Argentina (Scillato-Yané et al., 1998); and the Sopas Formation, Uruguay (Ubilla et al., 2004). Dolichotis cf. D. patagonum was mentioned for the late Pleistocene at Jesús María, Córdoba Province, Argentina (Sarrat, 2009) and Dolores Formation, Uruguay (Ubilla et al., 2009). D. salinicola was reported for the late Pleistocene of Buenos Aires Province (Tonni, 1981). A P4 of Dolichotinae indet. was reported for the continental shelf of southern Brazil (Rodrigues \& Ferigolo, 2004), but unfortunately these submarine deposits have no stratigraphic context, and the associated fossils encompass ages from Ensenadan to Lujanian (Lopes et al., 2010). Thus, Lagostomus cf. L. maximus described here is the first positive record of a Chinchillidae from Brazil, and Dolichotinae confirms the presence of this subfamily in the late Pleistocene of southern Brazil.

Lagostomus maximus usually lives in open areas, with grasslands or shrubs, often characterized by little rain (Eisenberg \& Redford, 1989). They are colonial diggers that live in colonial burrows systems, the "vizcacheras", which are occupied by many generations (Llanos \& Crespo, 1952; Villarreal et al., 2001). According to Villarreal et al. (2001), the vizcachas are found together with other mammals that indicate dry environments, such as the xenarthrans Chaetophractus villosus (Desmarest, 1804) and Zaedyus pichiy (Desmarest, 1804). Although predominantly associated with dry environments, Lagostomus seems to be more tolerant than Chinchilla and Lagidium, being found in arid to subtropical environments, with rainfall ranging from $<300 \mathrm{~mm}$ in west central region of Argentina to $>1000 \mathrm{~mm}$ in the north the country (Jackson et al., 1996). The dolichotines are cursorial rodents and restricted to arid and semi-arid environments (Einsenberg \& Redford, 1989; Campos et al., 2001).

Diverse taxa indicative of open areas and environments drier than today's have been reported for the late Pleistocene of southern Brazil, such as camelids, the tayassuid Catagonus and the rodent Microcavia (Scherer et al., 2007; Ubilla et al., 2008; Gasparini et al., 2009). However, the presence of Myocastor in Chuí Creek suggests the presence of permanent water bodies. These discrepancies perhaps can be explained by the presence of mosaic environments (Bombin, 1975; 1976). The palynological data available for the late Pleistocene of Rio Grande do Sul State suggest a predominance of open areas and grasslands (Bauermann et al., 2009 and references therein). Based on the ecology of the living taxa, the material reported here is consistent with this pattern. The presence of Lagostomus and Dolichotinae in southern Brazil, together with Microcavia which has a similar distribution, is probably related to the latitudinal displacements of the environmental and climatic belts during the late Pleistocene.

\section{ACKNOWLEDGEMENTS}

The authors thank the Conselho Nacional de Desenvolvimento Científico e Tecnológico $(\mathrm{CNPq})$ for financial support to L.K. and R.P.L. as fellowship of Programa de Pós-Graduação em Geociências/Universidade Federal do Rio Grande do Sul; CNPq (474485/2008-0) and Agencia Nacional de Promoción Científica y Tecnológica (Argentina, PICT 38112) for financial support; FZBRS and LGP-V FURG for the infrastructure provided; D. Sanfelice, D. Verzi and I. Olivares for the access to collections under their care; D. Verzi for helping us with the bibliography; P.V. de Oliveira, for help with the access to the material of Kerodon; J. Ferigolo, P. Hadler, F. Negri and M. Ubilla for reading and commenting the first version of the manuscript; C. Deschamps for improving the English version; the reviewers M.E. Pérez and A.H. Walton, and editors of Revista Brasileira de Paleontologia for their useful comments.

\section{REFERENCES}

Bauermann, S.G.; Behling, H. \& Macedo, R.B. 2009. Biomas regionais e evolução da paisagem no Rio Grande do Sul com base em paleopalinologia. In: A.M Ribeiro; S.G. Bauermann C.S. \& Scherer (orgs.) Quaternário do Rio Grande do Sul-Integrando Conhecimentos, Monografias da Sociedade Brasileira de Paleontologia, 1:81-93.

Bombin, M. 1975. Afinidade paleoecológica, cronológica e estratigráfica do componente de megamamíferos na biota do Quaternário terminal da Província de Buenos Aires (Argentina), Uruguai e Rio Grande do Sul (Brasil). Comunicações do Museu de Ciências e Tecnologia da PUCRS, 9:1-28.

Bombin, M. 1976. Modelo paleoecológico evolutivo para o Neoquaternário da região da Campanha-Oeste do Rio Grande do Sul (Brasil). A Formação Touro Passo, seu conteúdo fossilífero e a pedogênese pós-deposicional. Comunicações do Museu de Ciências da PUCRS, 15:1-90.

Bondesio, P.; Pascual, R. \& Vucetich, M.G. 1975. Los Neoepiblemidae (Rodentia, Caviomorpha): su caracterización y sus relaciones filogenéticas con los Chinchillidae: In: CONGRESO ARGENTINO DE PALEONTOLOGÍA Y BIOESTRATIGRAFÍA, 1, 1975. Actas, Tucumán, p. 431-447.

Buchmann, F.S.C.; Caron, F.; Lopes, R.P.; Ugri, A. \& Lima, L.L. 2009. Panorama geológico da planície costeira do Rio Grande do Sul. In: A.M. Ribeiro.; S.G. Bauermann \& C.S. Scherer (orgs.) Quaternário do Rio Grande do Sul-Integrando Conhecimentos, Monografias da Sociedade Brasileira de Paleontologia, 1:35-56.

Cabrera, A. 1961. Catálogo de los mamíferos sudamericanos II. Revista del Museo Argentino de Ciencias Naturales Bernardino Rivadavia, Ciencias Zoológicas, 4:(2):309-732.

Campos, C.M.; Tognelli, M.F. \& Ojeda, R.A. 2001. Dolichotis patagonum. Mammalian Species, 652:1-5.

Candela, A.M. 2005. Los roedores del "Mesopotamiense" (Mioceno tardío, Formación Ituzaingó) de la provincia de Entre Ríos (Argentina). In: F.G. Aceñolaza (ed.) Temas de la biodiversidad del litoral fluvial argentino II, INSUGEO, Miscelánea, 14:37-48.

Cartelle, C. 1999. Pleistocene mammals of the Cerrado and Caatinga of Brazil. In: J.F., Eisenberg \& K.H. Redford (eds.) Mammals of the Neotropics, The University of Chicago Press, p. 27-46.

Cione, A.L. \& Tonni, E.P. 1999. Biostratigraphy and chronological scale of uppermost Cenozoic in the Pampean Area, Argentina. Quaternary of South America and Antarctic Peninsula, 12:23-52.

Cione, A.L.; Tonni, E.P.; Bond, M.; Carlini, A.; Pardiñas, U.F.J.; Scillato-Yané, G.; Verzi, D. \& Vucetich, M.G. 1999. Occurrence charts of Pleistocene mammals in the Pampean area, eastern 
Argentina. Quaternary of South America and Antarctica Peninsula, 12:53-59.

Chimento, N.R. 2007. Nueva localidad fosilífera del Pleistoceno Tardio en Centro-Este de la Província de Buenos Aires, Argentina: In: JORNADAS ARGENTINAS DE MASTOZOOLOGIA, 21, 2007. Libro de resúmenes, Tafí del Valle, p. 236.

Cruz, L.E.; Fernicola, J.C; Carignano, C. \& Bargo, M.S. 2009. Nueva associación faunística del Pleistoceno del este de la Província de Córdoba. Ameghiniana, Suplemento 46(4):17R.

Eisenberg, J.F. \& Redford, K.H. 1989. Mammals of the Neotropics - The Central Neotropics. Chicago, Chicago Press, 609 p.

Flynn, J.J.; Wyss, A.R.; Croft, D.A. \& Charrier, R. 2003. The Tinguiririca Fauna, Chile: biochronology, paleoecology, biogeography, and a new earliest Oligocene South American Land Mammal "age". Palaeogeography, Palaeoclimatology, Palaeoecology, 195:229-259. doi:10.1016/S00310182(03)00360-2

Gasparini, G.M.; Kerber, L. \& Oliveira, E.V. 2009. Catagonus stenocephalus (Lund in Reinhardt, 1880) (Mammalia, Tayassuidae) in the Touro Passo Formation (Late Pleistocene), Rio Grande do Sul, Brazil. Taxonomic and palaeoenvironmental comments. Neues Jahrbuch für Geologie und Paläontologie, Abhandlungen, 254(3):261-273. doi: 10.1127/0077-7749/2009/0016

Gervais, H.F.P. \& Ameghino, F. 1880. Los mamíferos fósiles de la América del Sud. Igon Hermanos, Buenos Aires, 256 p.

Gómez, G.; Prado, J.L. \& Albedi, M.T. 1999. Micromamiferos del Sitio Arroyo Seco 2 (Provincia de Buenos Aires, Argentina). Sus implicaciones tafonomicas y paleoambientales. Estudios Geológicos, 55:273-281.

Huchon, D. \& Douzery, E. 2001. From the Old World to the New World: a molecular chronicle of the phylogeny and biogeography of hystricognath rodents. Molecular Phylogenetics and Evolution, 20:238-251. doi:10.1006/mpev.2001.0961

Jackson, J.E.; Branch, L.C. \& Vilarreal, D. 1996. Lagostomus maximus. Mammalian Species, 543:1-6.

Kerber, L. \& Oliveira, E.V. 2008. Fósseis de vertebrados da Formação Touro Passo (Pleistoceno Superior), Rio Grande do Sul, Brasil: atualização dos dados e novas contribuições. GaeaJournal of Geoscience, 4(2):49-64. doi:10.4013/gaea.20082.02

Kerber, L. \& Ribeiro, A.M. 2011. Capybaras (Rodentia, Hystricognathi, Hydrochoeridae) from the late Pleistocene of southern Brazil. Neues Jahrbuch für Geologie und Paläontologie, Abhandlungen, 261(1):1-18. doi: 10.1127/00777749/2011/0142

Kerber, L.; Ribeiro, A.M. \& Oliveira, E.V. 2011. The first record of Galea Meyen, 1832 (Rodentia, Hystricognathi, Caviidae) in the late Pleistocene of southern Brazil and its paleobiogeographic implications. Alcheringa, 35:445-457. doi: 10.1080/03115518.2011.533985

Kraglievich, L. 1930. Diagnosis osteológico-dentaria de los gêneros vivientes de la subfamilia "Caviinae". Anales del Museo Nacional de Historia Natural de Buenos Aires, 36:59-96.

Llanos, A.C. \& Crespo, J.A. 1952. Ecología de la vizcacha ("Lagostomus maximus maximus" Blaiv.) en el nordeste de la provincia de Entre Ríos. Revista de Investigaciones Agrícolas, 6(3-4):289-378.

Lopes, R.P; Buchmann, F.S.C; Caron, F. \& Itusarry, M.E. 2001. Tafonomia dos fósseis de vertebrados (megafauna extinta) encontrados ao longo das barrancas do arroio Chuí e linha de costa, RS, Brasil. Pesquisas em Geociências, 28(2):67-73.

Lopes, R.P.; Buchmann, F.S.C.; Caron, F. \& Itusarry, M.E.G. 2005. Barrancas fossilíferas do arroio Chuí, RS - Importante megafauna pleistocênica no extremo sul do Brasil. In: M. Winge; C. Schobbenhaus; M. Berbert-Born; E.T. Queiroz; D.A. Campos; C.R.G. Souza \& A.C.S. Fernandes (eds.) Sítios Geológicos e Paleontológicos do Brasil, Departamento Nacional da Produção Mineral, 2:1-10.

Lopes, R.P.; Kinoshita, A.; Figueiredo, A.M.G.; Baffa, O. \& Buchmann, F.S.C. 2010. ESR dating of Pleistocene mammal teeth and its implications for the biostratigraphy and geologic evolution of the Rio Grande do Sul coastal plain, southern Brazil. Quaternary International, 212(2):213-222. doi:10.1016/ j.quaint.2009.09.018

Lopes, R.P. \& Pereira, J.C. 2010. Fossils of Scelidotheriinae Ameghino, 1904 (Xenarthra, Pilosa) in the Pleistocene deposits of Rio Grande do Sul, Brazil. Gaea-Journal of Geosciece, 6(1):44-52. doi: 10.4013/gaea.2010.61.05

Lund, P.W. 1841. Tillaeg til de to Sidste Afhandlinger over Brasiliens Dyreverden för Sidste Jordomvaeltning. Det Kongelige Danske Videnskabernes Selskabs naturvidenskabelige og Mathematiske Afhandlinger, 8:273-296.

Marcon, G.T.G. 2008. Contribuição ao estudo dos Proboscidea (Mammalia, Gomphotheriidae) do Quaternário do estado Rio Grande do Sul, Brasil. Revista Universidade de GuarulhoGeociências, 7(1):93-109.

Oliveira, E.V. 1992. Mamíferos fósseis do Quaternário do Estado do Rio Grande do Sul, Brasil. Programa de Pós-Graduação em Geociências, Universidade Federal do Rio Grande do Sul, Dissertação de Mestrado, 118 p.

Oliveira, E.V. \& Pereira, J.C. 2009. Intertropical cingulates (Mammalia, Xenarthra) from the Quaternary of southern Brazil: systematic and paleobiogeographical aspects. Revista Brasileira de Paleontologia, 12(3):167-178. doi:10.4072/rbp.2009.3.01

Oliveira, E.V.; Prevosti, F.J. \& Pereira, J.C. 2005. Protocyon troglodytes (Lund) (Mammalia, Carnivora) in the Late Pleistocene of Rio Grande do Sul and their paleoecological significance. Revista Brasileira de Paleontologia, 8(3):215-220.

Paula Couto, C. 1950. Peter Wilhelm Lund-Memórias sobre a paleontologia brasileira. Rio de Janeiro, Ministério da Educação e Saúde/Instituto Nacional do Livro, 589 p.

Paula Couto, C. 1979. Tratado de Paleomastozoologia. Rio de Janeiro, Academia Brasileira de Ciências, 590 p.

Pérez, M.E. 2010. A new rodent (Cavioidea, Hystricognathi) from the middle Miocene of Patagonia, mandibular homologies, and the origin of the crown group Cavioidea sensu stricto. Journal of Vertebrate Paleontology, 30(6):1848-1859. doi: 10.1080/ 02724634.2010 .522432

Pocock, R. 1922. On the external characters of some histricomorphs rodents. Proceedings of the Zoological Society of London, 21:365-447.

Prado, J.L.; Menegaz, A.Z.; Tonni, E.P. \& Salemme, M.C. 1987. Los mamíferos de la Fauna local Paso Otero (Pleistoceno Tardío), Provincia de Buenos Aires. Aspectos paleoambientales y bioestratigráficos. Ameghiniana, 24:217-233.

Quintana, C.A. 1996. Diversidad del roedor Microcavia (Caviomorpha, Caviidae) en América del Sur. Mastozoologia Neotropical, 3:63-86.

Quintana, C.A. 1997. El roedor Dolicavia minuscula (Caviomorpha, Caviidae) del Plioceno Superior de la provincia de Buenos Aires, Argentina. Historia Animalium, 3:55-71.

Quintana, C.A. 1998. Relaciones filogenéticas de roedores Caviinae (Caviomorpha, Caviidae) de América del Sur. Boletín Real de la Sociedad Española de Historia Natural, Sección de Biología, 94:125-134. 
Rodrigues, P.H. \& Ferigolo, J. 2004. Roedores pleistocênicos da Planície Costeira do Estado do Rio Grande do Sul, Brasil. Revista Brasileira de Paleontologia, 7(2):231-238.

Rowe, D.L. \& Honeycutt, R.L. 2002. Phylogenetic relationships, ecological correlates, and molecular evolution within the Cavioidea (Mammalia, Rodentia). Molecular Biology and Evolution, 19:263-277.

Sarrat, C.M. 2009. Nueva localidad fosilífera del Pleistoceno de la provincia de Córdoba, Argentina: implicancias bioestratigráficas. Ameghiniana, Suplemento 46(4):37R.

Scherer, C.S.; Ferigolo, J.; Ribeiro, A.M. \& Cartelle, C. 2007. Contribution to the knowledge of Hemiauchenia paradoxa (Artiodactyla, Camelidae) from de Pleistocene of Southern Brazil. Revista Brasileira de Paleontologia, 10(1):35-52.

Scherer, C.S.; Pitana, V.G. \& Ribeiro, A.M. 2009. Proterotheriidae and Macrauchenidae (Liptoterna, Mammalia) from the Pleistocene of Rio Grande do Sul State, Brazil. Revista Brasileira de Paleontologia, 12(3):231-246. doi:10.4072/rbp.2009.3.06

Scillato-Yané, G.J.; Tonni, E.P.; Carlini, A.A. \& Noriega, J.I. 1998. Nuevos hallazgos de mamíferos del Cuaternario en el arroyo Toropí, Corrientes, Argentina. Aspectos bioestratigráficos, paleoambientais y paleozoogeográficos. In: CONGRESO LATINOAMERICANO DE GEOLOGÍA, 10/CONGRESO NACIONAL DE GEOLOGÍA ECONÓMICA, 6, 1998. Actas, Buenos Aires, p. 263-268.

Spotorno, A.E.; Valladares, J.P.; Marin, J.C.; Palma, E.R. \& Zuleta, C. 2004. Molecular divergence and phylogenetic relationships of chinchillids (Rodentia: Chinchillidae). Journal of Mammalogy, 85(3):384-388.

Tonni, E.P. 1981. Pediolagus salinicola (Rodentia, Caviidae) en el Pleistoceno tardío de la Provincia de Buenos Aires. Ameghiniana, 18(3-4):123-126.

Tonni, E.P.; Bargo, M.S. \& Prado, J.L. 1988. Los cambios ambientales en el Pleistoceno Tardío y Holoceno del sudeste de la Provincia de Buenos Aires a través de una secuencia de mamíferos. Ameghiniana, 25(2):99-110.

Tonni, E.P. \& Fidalgo, F. 1982. Geología y Paleontología de los sedimentos del Pleistoceno en el area de Punta Hermengo (Miramar, Prov. de Buenos Aires, Rep. Argentina): aspectos paleoclimáticos. Ameghiniana, 19(1-2):79-108.

Ubilla, M.; Oliveira, E.V.; Rinderknecht, A. \& Pereira, J.C. 2008. The hystricognath rodent Microcavia in the late Pleistocene of Brazil (Rio Grande do Sul, South America) (Mammalia: Caviidae): biogeographic and paleoenvironmental implications. Neues Jahrbuch für Geologie und Paläontologie Abhandlungen, 247:15-21. doi: 10.1127/0077-7749/2008/0247-0015

Ubilla, M. \& Perea, D. 1999. Quaternary vertebrates from Uruguay: a biostratigraphic, biogeographic and climatic overview. Quaternary of South America and Antarctic Peninsula, 12:75-90.
Ubilla, M.; Perea, D.; Aguilar, C.G. \& Lorenzo, N. 2004. Late Pleistocene vertebrates from northern Uruguay: tools for biostratigraphic, climatic and environmental reconstruction. Quaternary International, 114:129-142. doi:10.1016/S10406182(03)00048-X

Ubilla, M.; Perea, D.; Rinderknecht, A. \& Corona, A. 2009. Pleistocene mammals from Uruguay: biostratigraphic, biogeographic and environmental connotations. In: A.M. Ribeiro; S.G. Bauermann \& C.S. Scherer (orgs.) Quaternário do Rio Grande do Sul-Integrando Conhecimentos, Monografias da Sociedade Brasileira de Paleontologia, 1:217-230.

Ubilla, M. \& Rinderknecht, A. 2003. A Late Miocene Dolichotinae (Mammalia, Rodentia, Caviidae) from Uruguay, with comments about the relationships of some related fossil species. Mastozoología Neotropical, 10(2):293-302.

Verzi, D.H. \& Quintana, C.A. 2005. The caviomorph rodents from the San Andrés Formation, east-central Argentina, and global Late Pliocene climatic change. Palaeogeography, Palaeoclimatogy, Palaeoecology, 219:303-320. doi:10.1016/ j.palaeo.2005.01.003

Villarreal, D.; Branch, L.C.; Machicote, M. \& Hierro, J.L. 2001. Riqueza de especies en un gradiente de herbivoría de vizcachas (Lagostomus maximus Hollister). Revista de la Facultad de Agronomía-UNLPam, 12(1):41-54.

Vucetich, M.G., \& Verzi, D.H. 1995. Los Roedores Caviomorpha. In: M.T. Alberdi; G. Leone \& E.P. Tonni (eds.). Evolución biológica y climática de la Región Pampeana durante los últimos cinco millones de años, Monografías del Museo de Ciencias Naturales de Madrid, 12:211-225.

Vucetich, M.G.; Verzi, D.H. \& Hartenberger, J.L. 1999. Review and analysis of the radiation of the South American Hystricognathi (Mammalia, Rodentia). Comptes Rendus de la Académie des Sciences de Paris, Sciences de la Terre et des Planetes, 329:763-769.

Vucetich, M.G.; Vieytes, E.C.; Pérez, M.E. \& Carlini, A.A. 2010. The rodents from La Cantera and the early evolution of caviomorphs in South America. In: R.H. Madden; A.A. Carlini; M.G. Vucetich \& R.F. Kay (eds.) The Paleontology of Gran Barranca: Evolution and Environmental Change through the Middle Cenozoic of Patagonia, Cambridge University Press, p. 189-201.

Winge, H. 1888. Jordfundne og Nulevende gnavere (Rodentia) fra Lagoa Santa, Minas Geraes, Brasilien. E Museo Lundii, 3:1-178.

Wood, A.E. 1955. A revised classification of the Rodents. Journal of Mammalogy, 36(2):165-187.

Woods, C.A. \& Howland, E.B. 1979. Adaptive radiation of capromyid rodents: anatomy of the masticatory apparatus. Journal of Mammalogy, 60:95-116.

Received in April, 2011; accepted in November, 2011.

\section{Appendix 1. Comparative specimens.}

Caviidae: Dolichotis patagonum: MLP 8-XI-9-5, MLP 488, MLP 247, MLP 371 (Juvenile), MLP 5-II-49-2 (Juvenile), MLP 1418; D. salinicola: MLP 672 - 673; Kerodon rupestris: MDJ/Mr 002; Microcavia australis: MLP 683 (1-10), MLP 684 (1-23). Galea musteloides: MLP 738 (2, 4, 6, 7). Chinchillidae: Chinchilla laniger: MCN-M 2805, MLP 1767; Lagostomus maximus: MCPU-M 013, MLP 2-VI-607, MLP 5-II-49-4, MLP 359, MLP 5-IX-97-01, MLP 693, MLP 1597, MLP 1598, MLP 1599, MLP 1601, MLP 1602, MLP 1617, MLP 1636, MLP 1637, MLP 1639, MLP 1642, MLP 1649, MLP 1650, MLP 1656, MLP 1657, MLP 1659, MLP 1728, MLP 1729, MLP 1773, MLP 1774, MLP 1781, MLP 26-V-99-5, MLP 30-V-97-1, MLP 30-XII-02-3, MLP 19-V-98-1, MLP 1654, MLP 19-IX-47-3, MLP 19V-98-2, MLP 19-V-98-3, MLP 19-IX-47-4, MLP 25-X-95-2, MLP 26-V-99-6; Lagidium viscacia: MLP 1429, MLP 1432, MLP 20-V-961; Lagidium sp.: MLP 22-IV-47-4, MLP 343, MLP 377. 